\title{
Research on the Asset-Backed Securitization Financing of Large Stadium
}

\author{
Hongquan Li, Houzhong Jin \& Dan Wang \\ Sports Economics and Management School \\ Central University of Finance and Economics, Beijing 100081, China \\ E-mail: jinhouzhong@126.com
}

Received: November 12, 2010 Accepted: January 13, 2011 doi:10.5539/ibr.v4n2p90

\begin{abstract}
Along with the maturity and standardization of market, the asset-backed securitization financing is penetrating into the construction and operation of stadium, especially for the large stadium. In this paper, authors analyze the procedures of asset-backed securitization financing for stadium and the current situations, and put forward policy suggestions for the asset-backed securitization financing of large stadium in China.
\end{abstract}

Keywords: Large stadium, Asset-backed securitization, Financing

Asset-backed securitization refers to as ABS in the field. In this financing mode, the asset that lacks liquidity but generates cash flow can be transformed into transactional securities in finance market by structural reengineering, which can achieve the financing mainly by means of issuing bonds and asset- backed securities. At present, many countries have applied this kind of financing to the construction of urban infrastructure and stadium. The size and the nature of large stadium make it need more funds. A multi-channel financing is necessary. Besides, the post-operation of large stadium also needs a stable cash flow as the guarantee. Presently, in China the practical conditions and theoretical bases are the asset-backed securitization financing of large stadium.

\section{The process of asset-backed securitization financing of stadium}

The asset-backed securitization financing of stadium is a financing method in order to collect funds for the construction of stadium by means of issuing bonds in finance market, taking the charges for using the stadium and facilities as the base, and the future return or the official taxation as a guarantee.

The process of asset-backed securitization financing of stadium is: the sponsor sells the securitized stadium assets (such as membership income, TV right fee, naming right fee, rents, ads income, etc.) to the Special Purpose Vehicle (SPV), or the SPV buys in the securitized stadium assets actively, and collects these assets into an asset pool, then finances by issuing securities in financial market with the support of cash flow generated by the asset pool, finally pays off all issued securities with the cash flow. If the cash flow generated by the asset pool fails to pay off all issued securities, under some special conditions (such as the bonds are guaranteed by the government), the government will pay off these securities with taxes (Yanyang Jiang \& Yubo Xie \& Chunlin Deng, 2005, p173). See Figure 1.

\section{Present conditions of the asset-backed securitization financing of stadium}

In The United States, theories of asset-backed securitization financing of stadium and practices are highly developed. According to the Fitch Raings Company's grading securities of 38 units (23 government financing, 15 private financing), with the total sum 6 billion US dollars used for the construction of stadium and re-financing, 3.5 billion US dollars are from 23 tax-supported government security financing, and other 2.5 billion US dollars from 15 independent project financing or asset- backed stadium financing. Municipal bonds are always important in the American stadium financing. Almost all stadiums' financing includes the tax-supported municipal bonds and the income-backed securities. Obviously, the asset-backed securitization financing of stadium, as a new financing tool, is popular in practice and results in wonderful effects.

Domestic researches concerning the asset-backed securitization financing of stadium mainly focus on two aspects. The first is to study the asset-backed securitization financing in the country with developed sports industry, such as the United States, and learn from the experiences. For example, Chengjun Ju and Junying Lian (2007) analyze the advantages of asset-backed securitization financing of stadium in the United States, and suggest that the biggest problem of Chinese stadium financing is the simple financing structure. Objectively, China has the conditions for achieving the asset-backed securitization financing of stadium. We can learn from the United States, associating the construction of stadium with capital market, breaking the institutional barrier, and promoting the diversified development of stadium financing. Lingxiang Guan and Yongsong Zhou (2008) summarize the main channels for 
financing of foreign professional sports clubs, such as bond financing, equity financing, asset-backed securitization, and mention that foreign professional clubs have various financing channels, and rich experiences. We should learn from their experiences, and broaden the financing channels for the financing of professional sports clubs in China. The second is to study the advantages and disadvantages of asset-backed securitization financing of Chinese stadium. For example, Yanyang Jiang, Yubo Xie, and Chunlin Deng (2006) point out the advantages of asset-backed securitization financing of stadium are mainly lower financing costs than bank loans, lower financing risks, and lower risks of investors. The enlightenments from the asset-backed securitization financing of stadium in foreign countries are: we should issue general obligation bonds, unsecured debts, and asset-backed securities. Mei Wang and Liang Chen agree that today the construction of large stadium is in a dilemma with lagged behind government investment and social financing market malfunction. The institutional causes are immature exterior environment of market system and narrow construction objectives. The non-institutional causes are the characteristics of stadium and the lack of financing innovation. Relevant solution must be based on institutional innovation for stadium financing, insisting on the principle of effectiveness, enlarging and deepening the financing channels, construction projects, and operational products. The government should make up relevant policies to support the financing of stadium.

Generally speaking, we are still at the initial research stage concerning the asset-backed securitization financing of stadium in China. In recent years, the construction and operation of large stadium in China have adopted diversified financing. For example, for the construction and operation of stadiums for the 2008 Beijing Olympic Games, the PPP mode is for the construction of National Stadium, the BOT for the National Indoor Stadium and Olympic Village, donations from Hong Kong, Macao, and Taiwan for National Swimming Center, and the city government makes up the insufficient parts. All of them have tried to enlarge the stadium financing and achieved temporary fruits. However, compared with the United States, Australia, and some European countries with developed sports industry, these financing modes (PPP mode, BOT mode, etc.) are too simple and narrower.

\section{Policy suggestions for asset-backed securitization financing of large stadium in China}

\subsection{Build a government-dominated stadium asset-backed securitization financing market}

Compared with other financing ways, the stadium asset-backed securitization financing has lower costs and risks. Meanwhile, the self financing of stadium can get the support from the government. The stadiums for the 2008 Beijing Olympic Games have successfully tried different financing, what serve as valuable experiences. Therefore, to develop the asset-backed securitization financing of stadium, we should give full play to the advantage of low cost and risk, seize chances, and make best use of state policy support. At the initial development stage of stadium asset-backed securitization financing in China, the government should promote and support its development, by means of making up preferential policies, relevant laws, and supervision system, building a safe market system and transaction planning, performing financial regulatory and risk control by following the international practice, providing a relatively complete and regulatory environment for stadium asset-backed securitization financing, which includes the accounting system, the credit rating system, the financial guarantee system, and the taxation system, and regulating the choice of issuers, the conditions for issue of securities, the financial supervision, and risk control. In short, in order to promote the development of stadium asset-backed securitization financing in China, we should set up a government-dominated security guarantee or insurance, unify the guaranty application and contract, build a government- dominated stadium asset-backed securitization financing market, creating favorable conditions for the asset-backed securitization financing of stadium. Because of problems, such as the constraints of present sports system, the imperfect market system, and undeveloped financial market, for the asset- backed securitization financing of stadium, the governments at all levels have to issue bonds to improve the credit rating of stadium, escaping from threats from sports system, and sports market mechanism.

\subsection{Train amounts of institutional investors and open the stadium asset-backed securitization financing market to institutional investors}

Institutional investors have been the more important components in the capital market of sports industry in world developed countries. Institutional investors are the engines and sources for the liquidity of sports industry asset-backed securitization market. Therefore, with the precondition of the government strengthening the regulatory, the government must train the institutional investors who participate into the construction and operation of stadium and care about the development of sports industry, permit them enter the stadium asset-backed securitization market, and make them the real investment subjects of sports industry asset-backed securitization market. Because of the complexity of stadium asset-backed securitization financing, it is hard to make the giant stadium asset-backed securitization financing market work with personal funds. So, the training and entrance of institutional investors are very important for the asset-backed securitization financing of stadium in China. 


\subsection{Build an effective talent-market management mechanism}

The asset-backed securitization financing of stadium is a complex systematic project. In order to develop the stadium asset-backed securitization financing, we must introduce and train amounts of professional talents for managing and operating stadiums, improving present operations of stadiums, and guaranteeing the post cash flow. Meanwhile, we must establish the effective and reasonable employment mechanism, form the people-oriented management philosophy, rely on the market, recruit more capable people from the society, train and choose a group of experts who possess strategic insights, know about the financial market, sports industry, sports laws, and sports management, and excellent composite talents, insuring the orderly and effective operation of stadium asset-backed securitization financing in China. Also, we should cultivate sports entrepreneurs with the ability of asset-backed securitization market operation, achieving the innovation of sports industry's financing system, and establishing the incentive and constraint mechanism for the market operation of asset- backed securitization financing in sports industry in China.

\section{Conclusion}

Compared with the PPP mode and the BOT mode, the ABS financing mode involves with few stages, which reduces costs to a great degree. For the construction of large stadium, this financing mode means that the stadium has been profitable before it has been completed, turning fixed assets into circular securities. In China, because of the development of market economy, the construction of large stadium should adopt the diversified financing mode. We can learn from foreign countries' successful ABS financing modes and relevant studies serve as theoretical bases and intellectual supports. For the construction and operation of stadium, the main policy suggestions for the ABS financing mode are: build a government-dominated stadium asset-backed securitization market, train institutional investors and approve their entrance into the market, open the market to institutional investors, and set up the effective personnel market management mechanism.

\section{References}

Guan, Lingxiang \& Zhou, Yongsong. (2008). The enlightenments of main financing ways of foreign professional sports club. Market Modernization. No.1. p156-157.

Jiang, Yanyang. Xie, Yubo \& Deng, Chunlin. (2005). On the asset-backed securitization financing of stadium. Market Modernization. No.5. p173.

Ju, Chengjun \& Lian, Junying. (2007). Research on the asset-backed securitization financing of stadium in the United States. Shanxi Sports Science and Technology. No.8. p69-71.

Wang, Mei \& Chen, Liang. (2008). The cause analysis and countermeasures of financing market malfunction of large-scale sports stadium in China. Journal of Tianjin University of Sports. No.4. p360-364.

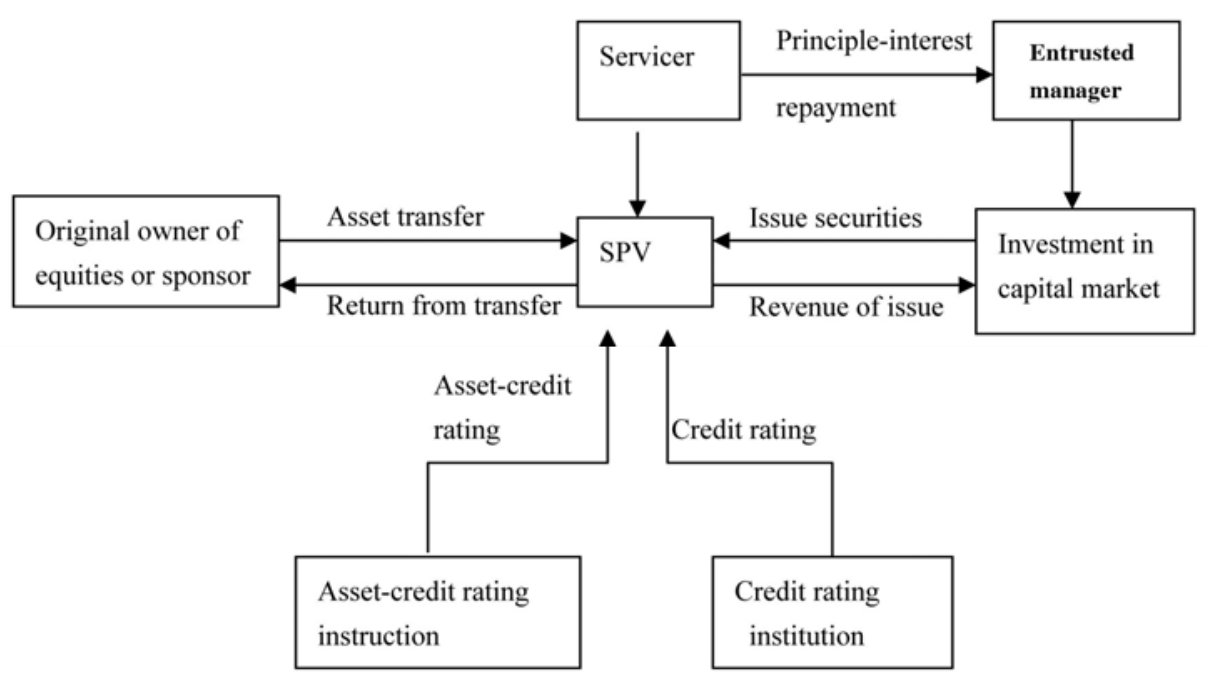

Figure 1. The ABS Financing Process for the Construction of Stadium 